\title{
DÍAS DE NARRAR. LA PROSA OFICIAL DE 1968
}

\author{
Pablo Tasso \\ Universidad Autónoma Metropolitana-Azcapotzalco
}

INTRODUCCIÓN: 1968 COMO GUERRA DE PALABRAS

La percepción estudiantil de que el gobierno de México quiso que la masacre de 1968 fuera olvidada tiene sus fundamentos. Fue la intención gubernamental inmediata y quizá es un deseo actual. Sin embargo, en los días y meses siguientes a aquel 2 de octubre de 1968, los altos funcionarios del gobierno de Gustavo Díaz Ordaz discutieron y construyeron un gran relato sobre el movimiento estudiantil. Un relato que para enfrentar las críticas y la incredulidad que el discurso oficial generaba entre la población, fue más allá de lo que hoy entendemos por una versión oficial. Su técnica más avezada fue camuflar su versión oficial entre las voces de la sociedad, entre las del grupo al que buscaba disolver, adaptando sus mensajes a los públicos en los que deseaba influir.

Fecha de recepción: 31 de octubre de 2014

Fecha de aceptación: 12 de junio de 2015 
En este trabajo buscamos presentar algunos escritos de esta versión. Entre estos escritos se encuentra la primera interpretación organizada que conocemos, un proyecto de versión oficial tradicional escrito en las oficinas de la Procuraduría General de la República (PGR). Se tituló Tlatelolco y fue abandonado en calidad de borrador cuando aún le faltaban fotografías y dibujos. ${ }^{1}$ De la Secretaría de la Defensa Nacional (sEDena) nació otro trabajo: Trampa en Tlatelolco, del general Manuel Urrutia Castro. Con esta crónica, la cúpula militar quiso limpiar la imagen del ejército ante los soldados y los funcionarios públicos del país. ${ }^{2}$ Otro trabajo es Los verdaderos acontecimientos de 1968, del general Luis Gutiérrez Oropeza, jefe del Estado Mayor Presidencial (EMP) de Díaz Ordaz. Permaneció casi 30 años guardado en un cajón porque atacaba al expresidente Lázaro Cárdenas, cuya sorpresiva muerte en octubre de 1970 le quitó su sentido. Que el primero y el tercero fueran desconocidos en aquel momento hace que nuestra lectura deba trascender al problema de la postura oficial sobre los hechos del 2 de octubre y centre nuestra atención en la narrativa oficial, puesto que en conjunto se revelan una perspectiva de razonamiento y una serie de análisis de la coyuntura política que hacen luz sobre la naturaleza de la élite burocrática de México. Como esta narrativa ocurre a propósito de una crisis política, es natural que en estos trabajos afloren los temores de la pérdida de control de la sociedad y muchas reflexiones sobre el 2 de octubre como experiencia gubernamental.

${ }^{1}$ AGN, IPS, PGR, Tlatelolco, c. 2688-A, fue difundido por DoyLe, "Los muertos de Tlatelolco", como "informe final" o "libro azul” de Julio Sánchez Vargas.

${ }^{2}$ Urrutia Castro, Trampa en Tlatelolco. 
Entre el grupo de textos que volvió especial a esta narrativa está jel móndrigo!, el libelo que ideó la Secretaría de Gobernación (SEGOB) para influir en el entorno estudiantil. ${ }^{3}$ Fue el primero de una saga de anónimos oficiales muy útiles para distorsionar la voz y controlar la mecánica de adhesiones de los sectores disidentes. ${ }^{4}$ Otro anónimo fue $\mathrm{Nue}$ vo movimiento estudiantil, una pieza de la estrategia de Luis Echeverría para incorporar a los jóvenes identificados con las causas y del movimiento estudiantil a trabajar en el Estado. ${ }^{5}$ En este grupo de textos también caben Tlatelolco, historia de una infamia y La plaza, en sintonía con el relato del gobierno, aunque escritos por personalidades reconocibles en la esfera de la opinión pública. ${ }^{6}$ Estos registros y voces literarias presentan, más que datos sobre el acontecimiento político y más que revelar alguna precisión sobre la masacre, un escenario de evolución de la retórica gubernamental mexicana.

Se ha prestado a esta historiografía menos atención de la que necesita. Las razones para olvidarse de ella han sido tan importantes como las que hoy justifican un análisis. El año ocupa un lugar destacado en la memoria colectiva, y muchas veces se piensa en él como un parteaguas en la historia contemporánea, como el momento en que la sociedad se movilizó ante el autoritarismo gobernante y lo rebasó, primero en las calles, y luego en su capacidad para imprimirle una interpretación al momento. El movimiento estudiantil abolló los

\footnotetext{
3 Anónimo, jel móndrigo! Bitácora del Consejo Nacional de Huelga.

${ }^{4}$ Entre ellos caben mencionar Ibarra, Danny, el sobrino del Tío Sam; Aguirre, El Excélsior de Scherer, y Godines, ; Qué poca mad... era la de José Santos Valdés!

${ }_{5}^{5}$ Caminante, Nuevo movimiento estudiantil.

${ }^{6}$ Blanco Moheno, Tlatelolco, historia de una infamia, y Spota, La plaza.
} 
símbolos del proyecto priista y, tras el choque, nada volvería a ser igual para ellos y la sociedad mexicana. Estudiantes y funcionarios aprenderían cosas distintas del mismo acontecimiento. Este artículo quiere presentar elementos sobre la evolución del sistema político y una lectura entre líneas del campo oficial como espacio de control político.

El movimiento estudiantil sacudió a la sociedad civil. Sin embargo, todavía es difícil entender qué despertó el movimiento en el gobierno además de los disparos del ejército. Mostró que podía saltarse "las trancas tan altas como se las pongan”, como había dicho Díaz Ordaz unos años antes. ${ }^{7}$ Luego del encarcelamiento masivo de estudiantes, el escenario político empezó a verse como una crisis. Ya no como un desafío en las calles, sino como la continuación de la "guerra de ideas” de 1968. Se pensó que el movimiento había provocado "un mar de confusiones" en el que el gobierno habría podido naufragar aun cuando "la gran mayoría del pueblo mexicano" hubiera permanecido "obediente a las instrucciones de la autoridad". ${ }^{8}$ Los diagnósticos posteriores a la masacre parecen claros: "la opinión pública se encuentra en desconcierto", conoce "unilateralmente, el punto de vista del Comité de Huelga”, de modo que estaba imponiéndose la perspectiva "de padres de familia influenciados por la propaganda de animadversión”. ${ }^{9}$ Mantener el silencio no parecía una opción. El gobierno debía construir "una exposición que clarifique" a la sociedad con "las versiones producidas por los elementos que tuvieron participación”, “mediante dibujos”

\footnotetext{
7 KraUze, La presidencia imperial, p. 317.

8 Urrutia Castro, Trampa en Tlatelolco, pp. 10, 11, 133.

9 AGN, IPS, PGR, “Tlatelolco”, c. 2688-A, f. 2.
} 
y "elementos fotográficos", 10 incluso con "el esplendor de una bruñida prosa", con "una nueva Divina Comedia". ${ }^{11}$

$\mathrm{Ni}$ funcionarios ni estudiantes tuvieron razones para recordar la versión oficial, y quizá estos materiales nos parezcan desconocidos. A los estudiantes se les acusó con ella de haber provocado al ejército para "tener unos muertitos" con los que llamar la atención del mundo. Además, la memoria estudiantil sería resultado del disenso con aquella "cárcel de palabras y conceptos" del gobierno. ${ }^{12} \mathrm{El}$ movimiento impuso su visión de 1968, los términos, y en general, los hechos de debate. Algo que no hubiera sido posible siguiendo los discursos del gobierno. A éste, estos libros le sirvieron como presentación de las políticas de la guerra sucia y para salvar algunos rasgos del ejército en el imaginario de los sectores más cercanos. Tras los primeros meses del gobierno de Luis Echeverría, debió parecer mejor no hablar de 1968. Con los años, acaso un par de generales parecieron continuar la discusión. ${ }^{13}$

Quizá haya que preguntarse cuál es el beneficio de analizar una visión engañosa y autoexculpatoria como ésta. El fenómeno de la historiografía de 1968 muestra que toda una generación mira su época en relación con este episodio. Desde la preocupación por aclarar la responsabilidad del Estado en la matanza, estas descripciones literarias se ven un poco

10 AGN, IPS, PGR, "Tlatelolco", c. 2688-A, f. 2.

11 Urrutia Castro, Trampa en Tlatelolco, p. 216.

12 Paz, Postdata, p. 250.

13 Casi tres décadas después, el general Gutiérrez Oropeza editó La realidad de los acontecimientos de 1968, y quizá como una reacción a ello se difundieron textos de García Barragán en Scherer y Monsiváis, Parte de guerra, Tlatelolco 1968. 
periféricas. Sin embargo, pensar en la narrativa autoritaria interesaría aun si no viviéramos en tiempos de su perfeccionamiento. De ahí que haya algunas razones para adentrarse en las ideas del gobierno acerca de la opinión pública. Y estos textos oficiales, quizá más que los hechos del movimiento estudiantil, dan acceso a un terreno de reflexiones sobre la composición social de la disidencia, acerca de sus hábitos de consumo de símbolos, tanto como acerca de las mejores maneras de representar una idea. Los trabajos oficiales revelan que la élite gobernante tenía muchos debates acerca del funcionamiento de la opinión pública, y que esta crisis permitirá poner en juego algunas nociones que circulaban acerca de los nuevos medios de comunicación y las formas de utilizarlos políticamente.

En este escenario, la versión de 1968 probó que el músculo narrativo del gobierno tenía que profesionalizarse y desarrollarse mucho todavía. No sabemos cómo se procesaría el fracaso de la versión oficial, pero es importante considerar que en el gobierno ya no se creía en la mentalidad infantil o primitiva del ciudadano promedio. Incluso se buscaba desde las oficinas superar el modelo censor. Se decía que las dictaduras eran aquellas que "reprimen por la fuerza las ideas y las expresiones populares”, mientras que en "un gobierno democrático" se debía controlar a la opinión pública por medio de la propaganda. ${ }^{14}$ Eso significaba hacer una propaganda que actuara de "estímulo, de excitante de la opinión pública” y que tuviera "calidad de arte”. Una propaganda

${ }^{14}$ Rodríguez Munguía, "La tiranía invisible", en La otra guerra secreta, p. 36. El autor analiza una propuesta sobre el uso de la propaganda encontrado en los archivos de Luis Echeverría, de 1964. 
capaz de "adoptar el lenguaje del grupo al que se quiere controlar", de usar "la palabra escrita para los mejor dotados", y otros medios para los "grupos de elevada incultura". ${ }^{15} \mathrm{Se}$ creía que una sociedad intercomunicada podía convencerse a sí misma sobre algún episodio y que el gobierno debía narrar más allá de los episodios controversiales. ${ }^{16}$

En sí misma, la versión oficial de 1968 es amplia, polifónica y por lo tanto difícil de abarcar. Analizar algunos materiales, que son de diferente tenor pero que constituyen en conjunto un proyecto oficial, nos permitirá avanzar con intenciones diversas. Una mirada puesta en los argumentos oficiales, por ejemplo, permitiría ver las diferentes estrategias para ensuciar el prestigio estudiantil mediante la creación de vínculos con el comunismo para luego poder adjudicarle la masacre como parte de un boicot internacional al gobierno de México. Las palabras incitación, conjura o trampa dan cuenta de ese rumbo. Desde una perspectiva política, podría ser revelador que la construcción de esta versión nos ofrezca al menos un libro de cada una de las oficinas de gobierno involucradas en el control del movimiento. A esta confluencia puede añadírsele el análisis de la coyuntura (interna y externa) que emerge en la óptica de estos trabajos. La interpretación del momento del partido, de la Iglesia, de la disidencia civil y de la enorme burocracia existente.

Analizar una versión, por otro lado, remite a las ocupaciones de la retórica y la literatura. Desde estas perspectivas podrían cobrar sentido los horizontes de los autores, sus

15 Rodríguez Munguía, "La tiranía invisible”, en La otra guerra secreta, pp. 40, 41 y 45 .

${ }^{16}$ En 1968 ya habría algunos frutos de una evolución, como la creación de la Agencia Mexicana de Noticias (Notimex), el 30 de agosto de 1968. 
lenguajes y su modelo de lector. En cuanto al abanico de lenguajes y formatos literarios, es fundamental observar cómo la crónica, el libelo, la novela o el ensayo se adaptan a públicos específicos: la tropa, los partidarios y funcionarios de segundo nivel, los jóvenes preparatorianos, etc. Para los pocos que aún creen en el discurso gubernamental: la crónica periodística; para los que simpatizan con el movimiento: el libelo de su intimidad; para el público general: la voz de escritores y periodistas reconocidos; etc. Una lectura sociológica advertiría, por otra parte, las horas de trabajo invertidas en la adaptación, la transcripción de materiales, la selección de fotografías, el dibujo de planos, la edición, todas tareas de oficinistas en proceso de especialización, y con miras a que el gobierno comunicara más y mejor.

Por considerar que algunos textos son poco conocidos, elegimos analizarlos por separado, favoreciendo una mirada historiográfica. La voz oficial fue acumulándose y sedimentando, por lo que debemos atender a su historicidad y a su ritmo de aparición. Y también, a que hay una dinámica fundamental que va de los hechos de 1968 a este proceso narrativo. Hasta el 2 de octubre, las fuerzas y oficinas oficiales habían trabajado intensamente para detener al movimiento estudiantil: se espiaban las reuniones, se perseguían estudiantes, se elaboraba un programa para detener al movimiento. Desde estas oficinas se había planeado arrinconar y detener a los miembros del Consejo General de Huelga (CGH) en diversos sitios de la ciudad: en la Casa del Lago de Chapultepec, en los edificios de la Ciudad Universitaria, en los del Politécnico Nacional, y finalmente en el barrio de Tlatelolco. El 2 de octubre el movimiento se apacigua en las calles. Del silencio inmediato surgen los rumores de la matanza de 
Tlatelolco. De la negación nacen las demandas de la memoria. Para las oficinas vienen días de narrar, y esa es la historia de este artículo.

VIERNES 5: CONFERENCIA DE PRENSA

Y ENTREVISTA EN LA TV

Después del 2 de octubre de 1968, la prensa y los medios de comunicación son el escenario de la primera acción comunicativa del gobierno mexicano. El suceso que ejemplifica la decisión gubernamental de imponer su versión es la conferencia de prensa en el Campo Militar número 1 de la Ciudad de México. Esta conferencia daría fama a Sócrates Campos Lemus, un estudiante del Politécnico que será el rostro de la versión oficial. Sin saber que lo observan periodistas, el estudiante detenido dice aquello que el gobierno necesita para sacudir la conciencia ciudadana. La noticia ocupó los titulares de los diarios del sábado. El estudiante admitía haber preparado una emboscada al ejército. En general, las condiciones de la conferencia, en las que el detenido se veía "a través de una vidriera" y escuchaba "a través de altoparlantes", no serían tan relevantes como las sensacionales declaraciones. ${ }^{17}$

En la revista por qué?, uno de los pocos medios opositores del momento, se preguntaban: “¿podía la prensa, con base en estas declaraciones, afirmar que la conjura había sido descubierta?" 18 En el siguiente número de la revista se transcribió una carta del estudiante detenido, sobre las horas anteriores a la conferencia: "a tal grado fueron las torturas, que

17 Ramírez, El movimiento estudiantil de México, p. 412.

18 Guzmán, "En el Campo Militar Número Uno: la gran farsa”, p. 22. 
una noche me encapucharon y me llevaron a un sitio lejano en donde escuchaba los gritos de dolor y de coraje del compañero Luis Cervantes Cabeza de Vaca. Comenzaron a disparar y nos decían que estaban fusilando a compañeros”. Cuando llegó el viernes, "se me sacó a declarar ante el agente del ministerio público federal, previa amenaza de muerte" y conducido a una sala en la que "luego me enteré que fue una rueda de prensa” ${ }^{19}$ La aclaración jamás lograría borrar el efecto de las muchas primeras planas en la prensa nacional. Una explicación antecede la edición número 21 de la revista por qué?: "la tercera parte de nuestro tiro anterior" fue "robado con el fin de ocultar a la opinión pública las graves aseveraciones que hace el dirigente estudiantil”. ${ }^{20}$

Para el día de la conferencia de prensa, en la Secretaría de la Defensa Nacional (sEDENA) se habían escrito al menos dos proyectos de explicación televisiva del 2 de octubre. Según un agente de la Dirección General de Investigaciones Políticas y Sociales (DGIPS), "el primer anteproyecto, elaborado por el General Marcelino Barragán”, contiene un "guión” para "el oficial que hará la explicación en Televicentro”. Después de analizar las propuestas, se habría acordado utilizar una "película” de la que se extraerían "algunas escenas” que "armonizan muy bien con el guión”. Con el apoyo de "una maqueta de toda la zona y una foto aérea", se harían "más claras las explicaciones del oficial” en la entrevista, se dice. Quedaba claro que aún faltaba el "guión definitivo", que tendría que escribirse una vez ensambladas las imágenes,

19 GuZmán, "Graves y sensacionales denuncias de Sócrates A. Campos Lemus”, p. 6. El documento está firmado el 24 de octubre de 1968, en la cárcel de Lecumberri. Cursivas en el original.

20 GuZmán, “¿Y las denuncias de Sócrates?”, p. 22. 
además de las "preguntas, incluso con cierto aire de duda", que haría el entrevistador. ${ }^{21}$

\section{UN PROYECTO DE VERSIÓN}

"Tlatelolco" es "un libro que se está preparando", como se indica en el índice. ${ }^{22}$ No registra la conferencia, y descuenta que "hasta estos momentos" "el gobierno no ha producido una exposición que clarifique los acontecimientos". ${ }^{23}$ Las primeras páginas constituyen un diagnóstico de la situación política, en especial la de "la opinión pública", que es considerada en "desconcierto". ${ }^{24}$ Contiene un informe del ejército, extractos de las declaraciones de los detenidos en el Campo Militar, el resumen de las autopsias de las víctimas y una serie de "dibujos ilustrativos" de lo que se buscaba instalar como la balacera de Tlatelolco. Aunque indica que se propone dar a conocer a los responsables, refleja mejor el momento inicial de la construcción de la versión oficial, cuando se están eligiendo los mejores ingredientes.

${ }^{21}$ AGN, IPS, c. 1459.

22 AGN, IPS, PGR, "Tlatelolco", c. 2688-A, p. 8. Doyle considera que se trata de "un reporte escrito por el Procurador General, Julio Sánchez Vargas", y permitiría establecer, "en forma indubitable, la procedencia y la dirección” de los disparos en la plaza. Y "si bien no identifica el responsable, sí precisa la ubicación del tirador respecto de la víctima”. Agrega que "se incluyen imágenes de la Plaza de las Tres Culturas, con esquemas que muestran los proyectiles de arma de fuego, creados con información incluida en los reportajes de autopsias". Doyle, "Los muertos de Tlatelolco". Tiene 131 páginas, y su evolución puede verse en la versión previa que también ha quedado entre los archivos políticos. AGN, IPS, PGR, Apuntes sobre Tlatelolco, c. 2865.

${ }_{23}$ AGN, IPS, PGR, "Tlatelolco", c. 2688-A, p. 3.

${ }^{24}$ AGN, IPS, PGR, "Tlatelolco", c. 2688-A, p. 6. 
Se propone "espigar la verdad", "reestructurar los sucesos", hacer y elegir "dibujos, planos y fotografías de los distintos ángulos de la Plaza”, mostrar "azoteas y relieves”, y señalar los "ángulos de visibilidad" para que fuera posible afirmar que las víctimas de esa tarde habían recibido disparos "desde lugares altos". Los "dibujos ilustrativos" permitirían convencer de las "trayectorias descendentes de las lesiones". ${ }^{25}$

Al final, suponía que "las declaraciones de los lesionados y asistentes al mitin" coincidían con "que los disparos se iniciaron desde el edificio Chihuahua", y con "los dictámenes periciales y las autopsias, que fijan en un noventa por ciento de las víctimas, trayectorias de proyectiles de arriba a abajo". ${ }^{26}$ Pero dentro del documento, el relato de los muertos era sangriento y contradictorio. Por ejemplo, se escribía que Cornelio Benigno Caballero Gandulfo "presentó en la autopsia, tres escoriaciones dermoepidérmicas, de 2, 1 y 11 centímetros". Que Fernando Hernández Chantre tenía "múltiples heridas" y "con fractura descubierta y fragmentaria del macizo craneano, facial y destrucción del encéfalo". Así, en una serie obvia de descripciones del efecto de armas de gran calibre, se sucedían casos como el de la "pérdida de masa encefálica" o "casi la totalidad de hemisferio cerebral izquierdo" de dos jóvenes no identificados. Incluso el caso de Jorge Ramírez Gómez, que recibió un proyectil que era "expansivo y causó la destrucción de la mitad de la cara”. ${ }^{27}$

\footnotetext{
25 AGN, IPS, PGR, “Tlatelolco”, c. 2688-A, pp. 2-7.

26 AGN, IPS, PGR, “Tlatelolco”, c. 2688-A, p. 123.

27 AGN, IPS, PGR, “Tlatelolco”, c. 2688-A, pp. 101-108. En esas páginas se hace mención de 26 personas, de las cuales la mitad habría muerto por disparos de trayectoria descendente. Esta narración es contraria a
} 
¿Podía explicarse la ofensiva estudiantil con estas descripciones? La propuesta era inverosímil aunque se ciñera a los deseos presidenciales. La defensa principal consistía en que al gobierno le tocaba "ser normativa de la paz interior de la nación”, así que "las peticiones" de cualquier grupo se resolvían "en función del interés de la mayoría" ${ }^{28}$ Con esto bastaba para explicar por qué "los elementos que forman parte de los cuerpos de policía, de seguridad y el ejército, se limitaron exclusivamente a dar garantías a la ciudadanía mexicana". ${ }^{29}$ Además, "se deduce que al acudir [...] con armas de fuego", los estudiantes lo habían hecho "en razón de un plan preconcebido". De modo que bastaba con "publicar las gráficas de este acontecimiento y reproducir las frases de los oradores" para que se pudiera "apreciar que su tono fue francamente hostil", como "altamente ofensiva" la "conducta de sus organizadores". Las pruebas surgían del "examen de las publicaciones y volantes que circularon tan profusamente el día de los acontecimientos". Con "la reproducción del texto de estos documentos", creían en la PGR, se podría "ilustrar acerca de la animadversión" que el movimiento estudiantil tenía para "con las autoridades". ${ }^{30}$

Una fotografía aérea y varios dibujos quedan como expresión de la voluntad de representar a los francotiradores, personajes clave de la explicación oficial. Los dibujos son una

la del director del servicio forense del Distrito Federal, que al "ampliar la información de carácter de médico legal ya rendida” decía que 4 personas habían fallecido de heridas de trayectoria descendente y 22 de trayectoria horizontal. AGN, DFS, exp.11-4-68, 1. 58, ff. 1 y 77.

28 AGN, IPS, PGR, "Tlatelolco", c. 2688-A, p. 6.

29 AGN, IPS, PGR, "Tlatelolco", c. 2688-A, pp. 6-7.

30 AGN, IPS, PGR, "Tlatelolco", c. 2688-A, p. 5. 
metáfora de la crítica y la superación de una construcción conceptual sobre otra. De los disparos como trazos en una plaza sin volumen, a una perspectiva de ojo de águila donde las rayas explotan. Pese a estos buenos intentos, la obra está llena de problemas. En la exposición inicial recuerda que hace apenas 25 años que el edificio del convento de Santiago Tlatelolco ha dejado de estar en manos del gobierno para regresar al clero. Había "servido de bodega a la Dirección de Bienes Nacionales durante sesenta años”. ${ }^{31}$ Además, "tanto el Convento de Santiago Tlatelolco como el Colegio de Santa Cruz, pasó a ser cuartel en el siglo pasado, sin que se sepa a ciencia cierta [...]” hasta qué fecha. Esto había ocurrido "basándose en la Ley de Nacionalización de Bienes Eclesiásticos dictada por don Benito Juárez el 12 de julio de 1859”. Además, el general Juan F. Baz, gobernador del Distrito Federal, había establecido que de los ocho cuarteles de la ciudad, el mayor, y el "número 1", fue “destinado al cuarto batallón y su alojamiento sería en Santiago Tlatelolco”. ${ }^{32}$

Pese a estos datos, la principal razón para abandonar “Tlatelolco" fue la conciencia de que la voz oficial no tenía credibilidad entre los sectores críticos. Al dejar la enunciación tradicional, el gobierno optó por métodos de comunicación alternativos para dirigirse a los sectores que lo enfrentaban. En la clasificación que los asesores de la Guerra Fría hacían esos años, "Tlatelolco" era una pieza de "propaganda blanca", porque se reconocía abiertamente "como procedente del gobierno”. Pero había otros métodos, como la propaganda "gris", que podía ser "atribuida a las personas

31 AGN, IPS, PGR, "Tlatelolco", c. 2688-A, p. 16.

32 AGN, IPS, PGR, "Tlatelolco", c. 2688-A, p. 19. 
u organizaciones" distantes del gobierno; o la "propaganda negra" que era "anónima, o se atribuye a una fuente que no existe, o es material falso atribuido a una fuente real". ${ }^{33}$ A partir de este momento, sólo para los sectores que los apoyaban, el gobierno produciría propaganda blanca, como podría haber sido "Tlatelolco" de haberse publicado.

BUSCANDO A DANTE: LA CRÓNICA MILITAR

Como dijimos, Trampa en Tlatelolco, del general Manuel Urrutia Castro, se convirtió en la postura del ejército ante la burocracia y los soldados del país. Es una de las más extensas versiones gubernamentales, tal y como esto podía ser comprendido en ese momento en la SEDENA. Es una mezcla de testimonio, crónica y ficción, y la puesta en escena de la traición estudiantil a la mano tendida del gobierno. Está firmada por un general reconocido y en su interior se reproduce una entrevista del secretario de la Defensa. Fue regalado y distribuido desde las oficinas del ejército a todas las dependencias y zonas militares del país, como sucede con las políticas de Estado. ${ }^{34}$ Tiene 226 páginas, y aunque no tiene fecha de edición, el libro se terminó de escribir a finales de 1969. Su perspectiva es la de Marcelino García Barragán, aunque también era obsequiado por el propio Díaz Ordaz. ${ }^{35}$

33 AgeE, Inside the Company, p. 71.

${ }^{34}$ AGN, SEDENA, c. 46. 1. 134.

${ }^{35}$ Esto es relevante, sobre todo si se tiene en cuenta que otros textos, como “Tlatelolco" y el proyecto de Gutiérrez Oropeza, La realidad de los acontecimientos de 1968, no fueron aprobados ni apoyados por el gobierno. 
Quizá el presidente lo regalaba porque el dibujo de la tapa, del pintor Luis Strempler, le había dado forma a su metáfora de la mano tendida, argumento central de su discurso del $1^{\circ}$ de septiembre de 1968. La imagen está construida con la expectativa de no dejar dudas acerca del espacio donde acontece el relato. En primer plano, un soldado y un estudiante estrechan sus manos. Atrás, la plaza se dibuja con sus edificios principales: la preparatoria, el edificio Chihuahua, la iglesia de Santiago Tlatelolco y la torre de Relaciones Exteriores son el escenario de la reconciliación. En el centro, los restos de la antigua ciudad toman la forma de un libro abierto, como si fuera necesario aprender de la masacre. El libro sostiene los símbolos más socorridos del relato oficial: una pirámide con el escudo nacional.

Urrutia también hace una buena descripción de la crisis en la opinión pública y a la vez registra cómo el gobierno fue percibiendo que el movimiento ganaba el apoyo de la sociedad. Desde el día 28 de julio "empezaron a circular panfletos" escritos con una "verborrea incendiaria" que resultaban un material poderosamente "desorientador para algunos grupos", incluso al "funcionario responsable, a un obrero o a un campesino". "Veía la situación como una "guerra de ideas", o como una "contienda de palabras" que amenazaba con cambiar el rumbo de las opiniones del mexicano. ${ }^{37}$ Se trataba de un "feroz combate de palabras" que amenazó quebrar el consenso del que gozaba el gobierno. En la carrera por publicar su trabajo, Urrutia le pone palabras a la desesperación por la pérdida de credibilidad. Luego de 1968 “ya

\footnotetext{
36 Urrutia, Trampa en Tlatelolco, pp. 38 y 11.

37 Urrutia, Trampa en Tlatelolco, pp. 10-11.
} 
no se sabía quién era de acá y quién era de allá”, y la voz del gobierno bien podía sentirse, como Urrutia, dentro de "una ensalada" de discursos, girando en esa "revoltura que nos cocinaron los enemigos". 38

Advierte que no ha escrito "para crear abismos entre dos sectores tan importantes como son los estudiantes y los militares", sino para hacer ver que es indispensable "que México no distraiga sus esfuerzos en andar apaciguando mitotes". ${ }^{39}$ Desde el prólogo argumenta que su propósito es limpiar la reputación de una "institución tan seria y respetable como es el ejército Mexicano". ${ }^{40} \mathrm{El}$ modo en que Urrutia cree que puede recuperar ese prestigio es haciendo propaganda de su labor social, lo que en el texto consistía en reproducir un relato de la "actividad cotidiana" del ejército en el marco del llamado “Plan DN III”. Así, su cronología no inicia el 22 de julio, sino el 7 de julio, cuando el Ejército "ayudó a los colonos” de Ciudad Juárez “a desalojar sus casas y rescatar sus pertenencias con motivo de la tormenta que azotó a dicha ciudad". O cuando hizo lo mismo "el día 8 al salirse de su cauce el río Bravo". 41

El libro es la primera exposición de documentos sobre el 2 de octubre, pues incluye una serie de "contundentes pruebas”. Según su plan, durante "el trayecto de este libro, cuyo método será la narración sincronizada cronológicamente

${ }^{38}$ Urrutia, Trampa en Tlatelolco, p. 131.

${ }^{39}$ Urrutia, Trampa en Tlatelolco, p. 64.

${ }^{40}$ Urrutia, Trampa en Tlatelolco, pp. 10 y 11.

${ }^{41}$ Urrutia, Trampa en Tlatelolco, pp. 31-32. La alusión al plan de Defensa Nacional en situaciones de desastre (Plan DN III) se ha usado desde ese momento para ensombrecer las acciones de la seguridad interior, también llamado combate a la insurgencia interna (Plan DN II). 
de los hechos", el autor logrará "probar [...] esa verdad nuestra". ${ }^{42}$ Reconoce la dificultad de cambiar la percepción social sobre el ejército: "la lucha contra la calumnia" puede volverse "una lucha estéril", porque deja un "lastre de los infundios que estigmatiza". Pero es optimista en el sentido de que "el ejército tiene una trayectoria tan limpia y su comportamiento ha sido tan vertical" que "bien podría exclamar lo que el vigoroso bardo jarocho Díaz Mirón”:

Los claros timbres de que estoy ufano han de salir de la calumnia ilesos.

Hay aves que cruzan el pantano y no se manchan: mi plumaje es de esos. ${ }^{43}$

La narración cronológica le da a Urrutia la oportunidad de reseñar a las voces críticas a la revuelta estudiantil. Las páginas se llenan así de notas periodísticas: "la prensa del día 27 comentaba" [...] "por ejemplo, en el Excélsior del 1ํㅡㄹ de agosto leíamos [...]”, o "en las páginas de El Sol de México el escritor Francisco Ruiz Colunga, se expresaba”, etc. ${ }^{44}$ Con la conclusión de que "casi toda la prensa de esa fecha" había "celebrado la intervención del Ejército" ${ }^{45}$ Además de las transcripciones periodísticas, el propósito de legitimar la actuación presidencial se lograba con la reseña de los apoyos de "los sectores más activos del país", es decir, de "los representantes de los sectores privados". La Confederación de Cámaras Nacionales de Comercio (concanaco), la Confederación de Cámaras

\footnotetext{
42 Urrutia, Trampa en Tlatelolco, p. 11.

43 Urrutia, Trampa en Tlatelolco, p. 52.

44 Urrutia, Trampa en Tlatelolco, pp. 36-67.

45 Urrutia, Trampa en Tlatelolco, p. 136.
} 
Industriales (CONCAMIN), la Cámara Nacional de la Industria de Transformación (CANACinTRA), la Asociación de Banqueros, el presidente de la Cámara de Comercio, "y otros representantes de la iniciativa privada, hicieron declaraciones" en favor del gobierno: la presentación de Díaz Ordaz el 1ํㅡㄹ septiembre de 1969, en el tradicional mensaje en el senado, había estimulado a la sociedad a opinar, y cada vez más personas "acudían a solidarizarse con el señor presidente". ${ }^{46}$

Más allá del espíritu conciliador del dibujo de Strempler, Urrutia produce uno de los retratos estudiantiles más hirientes de esos días. Entre sus fotos, citas y documentos, el autor se inventa un "connotado apátrida y truhan" que hace las veces de líder estudiantil modelo, a quien le adjudica una conversación frente a su "círculo de amigos". Este "enemigo del pueblo" se "mofaba de su actuación" durante la toma del edificio Politécnico el 29 de julio de 1968. Se llamaba Ferrini, y había ido con la idea de "volar la puerta en el momento de que fueran a entrar los soldados". Para ello había preparado un "buti de botellas molotov", con el fin de "matar a algunos" y con eso "encender a la juanada". De este modo, según sus planes, el ejército entraría "matando a cuanto cristiano se pusiera enfrente" ${ }^{47}$ Urrutia también encuentra en "el doctor Fausto Trejo, profesor de la vocacional 7", una "figura para el escándalo". Un profesor que se aprovechaba del aula "para darle rienda suelta a su verborrea demagógica”. Decía que había que ver en él al "clásico maestro-político-agitador" que desde su púlpito escolar "empujaba con encendida requisitoria" a esos "mozalbetes irreflexivos para que según el decir de este mentor

\footnotetext{
46 Urrutia, Trampa en Tlatelolco, pp. 69-70.

47 Urrutia, Trampa en Tlatelolco, pp. 50-51.
} 
dejarán de ser pusilánimes y cobardes" al enfrentarse al gobierno. Urrutia no ahorra adjetivos en su retrato de esos "seres" de "refinados instintos bestiales", "tragicómicos actores", que deben ser "situados en las cámaras letrínicas correspondientes a su grado de perversidad". "Por oposición, el verdadero estudiante es en realidad una "mansa muchedumbre de jóvenes" que "se encontraba descarriada" y víctima de los agitadores. ${ }^{49}$

Dijimos que existe la idea de que el gobierno de México produjo un silencio sobre el 2 de octubre. Que buscó arrumbar estos episodios en un cajón, propiciando el olvido; pero Urrutia está convencido de que el gobierno no sólo tiene que dar explicaciones, sino que debe "hacer historia de esa fecha". ${ }^{50}$ Reconoce que se tienen pocas posibilidades de cambiar la percepción por lo que es necesario reforzar la tarea de la elaboración de la versión oficial, con más y mejores escritores. No pide nuevos heródotos, sino un "Dante Alighieri”, al fin, "un autor de una nueva Divina comedia". No uno, sino varios, "para que se nos relaten con el brillo y esplendor de una bruñida prosa, estos pasajes de la historia”. ${ }^{51}$

\section{EL PANFLETO OFICIAL}

Los funcionarios de la Secretaría de Gobernación se lanzaron por la construcción de un libelo. Usaron la información de las reuniones del consejo de huelga - provista por la Dirección Federal de Seguridad (DFS) - y publicaron jel móndrigo! Bitácora del Consejo Nacional de Huelga. Su propuesta

\footnotetext{
48 Urrutia, Trampa en Tlatelolco, p. 216.

49 Urrutia, Trampa en Tlatelolco, p. 118.

50 Urrutia, Trampa en Tlatelolco, p. 11.

51 Urrutia, Trampa en Tlatelolco, p. 216.
} 
era para los “ciudadanos libres”, como se decía en la secretaría, para los que eran "capaces de resistirse" a la propaganda oficial. ${ }^{52}$ Profesores universitarios, periodistas, escritores, artistas y líderes sociales habían hecho sentir con claridad su apoyo a los estudiantes y constituían un grupo de opiniones antigubernamentales bastante definidas. jel móndrigo! era una larga descalificación que tuvo por objeto crear sospechas sobre los comportamientos de los líderes estudiantiles, pero también estigmatizar a varios referentes del grupo de artistas e intelectuales que los apoyaba. Su objetivo era detener la lógica de adhesión que había despertado el movimiento. Está entre los libros más reproducidos sobre 1968 en aquellos años, y más que una acusación contra los estudiantes, es una puesta en escena de la traición estudiantil al llamado orden institucional.

Tiene todas las características del libelo como ha sido conocido éste en la historia de la literatura política. Anónimo, sin casa editorial, de prosa envenenada, sobre personajes reales, etc. ${ }^{53}$ En lugar de las aventuras sexuales típicas del libelo francés, los personajes de ¡el móndrigo! son homosexuales y consumen drogas alucinógenas. Aunque lejos de ser un producto marginal del poder, que evadía los controles para circular, este era producto de las mismas oficinas censoras. Su edición no era perseguida por policías, sino auspiciada y distribuida por ellos. ${ }^{54} \mathrm{Su}$ audacia mayor fue preten-

52 Rodríguez Munguía, "La tiranía invisible”, en La otra guerra secre$t a$, p. 43. Este trabajo se refiere en varias ocasiones a la dificultad de convencer a los "sectores antagónicos" y a los "núcleos mejor capacitados" con una propaganda fuera de lo común.

53 Véase Courier, Pamphlet des pamphlets; SAwyer, Printed Poison.

54 Sobre las razones por las que los libelos y panfletos eluden la identi- 
der camuflar a sus autores y lograr ser leído como una voz genuina en el campo estudiantil: como el diario íntimo de un líder del Consejo de Huelga. Estructuralmente está muy cerca de Los días y los años, la novela más leída de esos años, pues trata sobre "los sucesos más salientes del movimiento estudiantil". 55

La fotografía de la portada de la primera edición y el prólogo explicarían al lector la ausencia de datos del autor, la situación del hallazgo del supuesto manuscrito, aunque no así el nacimiento de la casa editorial..$^{56}$ Se trata, según el prólogo, de un texto encontrado "bajo la cintura y fuertemente sujeto" al cadáver de un joven muerto el 2 de octubre.

ficación y son producto de la clandestinidad, FARGE, Subversive Words. Claro que Darnton ha demostrado que la historia del libelo está ligada íntimamente a los actores políticos, que son quienes lo han usado para incidir en sus disputas. Véase DARnton, El diablo en el agua bendita.

55 Anónimo, jel móndrigo! Bitácora del Consejo Nacional de Huelga, p. 5. En este sentido, el libro de Gobernación es la contracara de la novela de González de Alba, Los días y los años.

${ }^{56}$ Alba Roja remite al texto de Vargas Vila, Alba Roja, que retrata a dos jóvenes colombianos que unen, en una suerte de fervor iniciático, la pasión política con la tragedia personal. Podría ser esta una evocación literaria de ese grupo de políticos que desde la Secretaría de Gobernación se sentían también referentes intelectuales de la vida nacional, como Mario Moya Palencia - director de la oficina de prensa, radio y televisión - o Fernando Gutiérrez Barrios - director de la Dirección Federal de Seguridad-. Sobre el primero véanse las comparaciones del prólogo de su libro de 1991, Moya Palencia, El México de Egerton. Sobre Gutiérrez Barrios véase Ortega, presenta el registro de "lecturas recurrentes" de su personaje: El príncipe de Maquiavelo, La psicología de las multitudes, de Gustav Le Bon, El águila y la serpiente de Guzmán... Y otros autores latinoamericanos: Borges, García Márquez, Asturias, Galeano, "y muy especialmente, Alejo Carpentier". ORTEgA, Fernando Gutiérrez Barrios, p. 24. 
El "legajo manchado de sangre fresca" era el "diario íntimo" del CNH, del que este era "uno de sus líderes". Era anónima porque a su autor "nadie lo identificó". ${ }^{57}$ Se editó dos veces y se hicieron muchas reimpresiones. La segunda edición amplió el prólogo y cambió gran parte de las ilustraciones, incluyendo la portada. Con esos cambios se incorporarán algunas frases que probablemente reflejan la sensibilidad oficial ante las sospechas de los lectores de que estaban ante un libro engañoso. Donde se decía que nadie lo había identificado ahora se agrega que, "en este tipo de luchas, ninguno usa credencial. Y si lo conocieron, se hicieron los desentendidos para no comprometerse". ${ }^{58}$ En cuanto a las fotografías, alguien debió considerar que las imágenes que se habían escogido para la primera edición realzaban la lucha estudiantil - que tanto se buscaba desmerecer-, como la fotografía del día 22 de julio. En ella unos jóvenes desafiantes y con piedras en las manos miran al fotógrafo y los granaderos en la Ciudadela. ${ }^{59}$ Otras fotografías, que también serían eliminadas, evidenciaban la posición del fotógrafo, como una del mitin del 5 de agosto tomada desde el palacio del gobierno del Distrito Federal. De modo que en la segunda edición se usaron fotografías menos significativas, que reflejaran la derrota estudiantil o las acciones más criticadas, como la quema de camiones. Los cambios mostraban que el camuflaje oficial tenía defectos, pero funcionaba y podía hacerlo mejor. Los datos del espionaje del movimiento estudiantil sirvieron para situar personas y momentos claves por los que

57 Anónimo, jelmóndrigo! Bitácora del Consejo Nacional de Huelga, p. 5.

58 Anónimo, jel móndrigo! Bitácora del Consejo Nacional de Huelga, p. 5.

59 Anónimo, jel móndrigo! Bitácora del Consejo Nacional de Huelga, p. 7. 
parecía deambular el narrador. ${ }^{60}$ De estos documentos surgen los nombres de oradores, procedencias escolares, horarios, fechas y asuntos de discusión. Esta precisión le dio verosimilitud al relato, y quizá por ello produjo un efecto entre quienes tenían poco conocimiento de las trampas políticas de la época como para leer el texto bajo la sospecha de su procedencia. Con la impostura narrativa construida a partir de la información de inteligencia, el texto avanzaba hacia su principal objetivo: producir un retrato estudiantil que obtuviera toda la antipatía o el rechazo que fuera posible.

El retrato era el siguiente: formaba parte de la "línea dura" del movimiento. Todo el tiempo había sido "partidario de la rebelión armada y demás medidas violentas”. Descreía de "las inocuas e infantiles pintas", y era lo que en la jerga de la época se llamaba un "acelerado". ${ }^{61}$ Era artífice y provocador de varios embates policiales: la destrucción de la puerta de San Ildefonso, la asonada en el Zócalo, la masacre del 2 de octubre. Como el Ferrini de Urrutia, que el 16 de septiembre insiste en empujar la puerta y entrar al Palacio Nacional, jel móndrigo! pide como demanda a Díaz Ordaz "unos muertitos", o al menos "varias docenas de heridos". Todo sea para sostener al movimiento. ${ }^{62}$ Como era creencia popular, los “muertos son indispensables” para obtener la cohesión y el

${ }^{60}$ Hemos comparado los reportes de la Dirección Federal de Seguridad con el texto aludido en TAsso, "El Móndrigo y la literatura del poder", y "La historiografía oficial de 1968”, pp. 67-69.

${ }^{61}$ Anónimo, jel móndrigo! Bitácora del Consejo Nacional de Huelga, p. 8. La palabra acelerado se usó para definir al ala estudiantil más radical, según Martré, El movimiento popular estudiantil de 1968 en la novela mexicana, p. 145.

${ }^{62}$ Anónimo,jelmóndrigo! Bitácora del Consejo Nacional de Huelga, p. 142. 
consenso social sobre el movimiento, hacen de "mezcla, de cemento, o ligazón”. Sin ellos, “`cómo gritar ¡represión!?”. ${ }^{63}$

El plan "consistía en esconder en diversos edificios contiguos al Chihuahua a varias columnas de estudiantes y maestros convenientemente armados". De modo que "cuando el ejército acordone al mitin, a una señal dispararán contra los soldados; y éstos, al contestar, lo harán sobre los estudiantes y gente del pueblo congregados en la plaza”. No hay duda, anota el héroe, "la matanza será segura", llevaría a una crisis nacional y "cuarenta y ocho horas después, el paro general”. Según el cálculo, "los desórdenes en todo el país harán caer al gobierno, y el poder pasará a nuestras manos”. ${ }^{64}$

El retrato era necesario para reducirle al movimiento estudiantil sus posibilidades políticas, pero motivar simpatías para los actos del gobierno suponía otras dificultades. La masacre de Tlatelolco sucede en vísperas de un gobierno que producirá grandes cambios. Entre ellos, la creación de muchos puestos de trabajo. Cuesta desentrañar a una voz impostada, cuesta dilucidar si escribir que "miles de personas" estarían "dispuestas a luchar de nuestro lado", expresa una preocupación estudiantil o es una de las reflexiones del grupo echeverrista en esa coyuntura. Desde el ángulo oficial se entiende el optimismo, en el sentido de que "no solamente el temor a perder la libertad puede darnos ambiente y abrir un camino", que para el grupo sería el llamado camino de la apertura democrática. ${ }^{65}$

63 Anónimo,jelmóndrigo! Bitácora del Consejo Nacionalde Huelga, p. 148.

64 Anónimo,jelmóndrigo! Bitácora del Consejo Nacional de Huelga, p. 177.

65 Anónimo,jelmóndrigo! Bitácora del Consejo Nacional de Huelga, p. 82. 
Además de frases surgidas de las oficinas de policía, jel móndrigo! parece contener algunos fragmentos de los análisis que se hacían de la situación en la oficina del propio secretario de la SEGOB. Así se entienden los planes a mediano plazo de "atraer y captar a nuestro campo" a diferentes sectores del país. La preocupación de "usar hábiles métodos de atracción". Se trata de acercar a "los políticos postergados", "los escritores hundidos en la estrechez económica", "los intelectuales que pasan más como tales que lo que son", pero también a "los obreros, los campesinos y los pequeños burgueses" ${ }^{66}$ Estas frases, más allá de la boca en que son puestas, reflejan las ideas que rondan el momento en que se diseñan las políticas de la apertura política. En ese proceso no se piensa en incorporar a los jóvenes como "militantes afiliados al partido - que a ellos no les conviene ni a nosotros tampoco - sino como servidores" ${ }^{67}$ No sólo se trata de adhesión compulsiva "por codicia, por miedo, por interés, por inferioridad, por venganza o por lo que sea", sino también del reconocimiento de que la mayoría de los partidarios, al fin, "tampoco actúan con limpias intenciones". ${ }^{68}$ Había que aceptar que "la inmensa masa de nuestros amigos y adictos está formada de oportunistas". ${ }^{69}$

También destaca la preocupación por disciplinar a los empleados públicos, espacio al que los estudiantes habían logrado involucrar. Se podía convertir en "blanco de ataque frontal" a todo "político o funcionario que no jale con nosotros". Según el argumento, sería "suficiente que haga-

${ }^{66}$ Anónimo, jelmóndrigo! Bitácora del Consejo Nacional de Huelga, p. 85.

${ }^{67}$ Anónimo, jelmóndrigo! Bitácora del Consejo Nacional de Huelga, p. 82.

68 Anónimo, jelmóndrigo! Bitácora del Consejo Nacional de Huelga, p. 85.

${ }^{69}$ Anónimo, jelmóndrigo! Bitácora del Consejo Nacional de Huelga, p. 86. 
mos escarmiento de uno" como una forma de lograr que los espectadores "se convenzan de que tenemos capacidad de cerrarle el camino a alguien y convertirlo mediante nuestra campaña en un verdadero palo de gallinero que no haya por donde tomarlo". Para lograr el objetivo, no habría muchos límites, "inventarle todo" con tal de "dejarlo en la miseria moral”, hasta dejarlo como "un miserable guiñapo arrollado y amasado en su propio fango [...] en ese fango que hayamos fabricado para él”. ${ }^{70}$ Para quienes no se dejaran atraer y persistieran en la rebeldía estudiantil, sólo quedaba el camino de las armas. Habían cometido muchos errores, un “arrojo insensato, que tan sólo conoce el avance y no conoce la retirada". Su "miopía militar" los había hecho equivocarse. Por "temor a verse privados de territorio" se pusieron a combatir "por cada palmo de tierra”, y ahora "no sólo pierden la ciudad y el territorio, sino que tampoco pueden conservar sus fuerzas". ${ }^{71}$ Su única opción era irse "al monte a la guerrilla y al terrorismo" ${ }^{72}$

Es evidente que en el gobierno estaban muy entusiasmados con la factura literaria y con los efectos de jel móndrigo! $\mathrm{Ni}$ al general Manuel Urrutia le resulta indiferente la visibilidad y circulación de su competencia. Por eso dice que "la llamada Bitácora del Consejo Nacional de Huelga de la editorial Alba Roja” era una confirmación de la mentalidad estudiantil. Y en cuanto a "si debemos dar crédito" o no, cree que “no tenemos por qué no”. Acaso habrá que esperar

\footnotetext{
70 Anónimo, jel móndrigo! Bitácora del Consejo Nacional de Huelga, pp. 84-85.

71 Anónimo, jel móndrigo! Bitácora del Consejo Nacional de Huelga, pp. 139-140.
}

${ }_{72}$ Anónimo, jelmóndrigo! Bitácora del Consejo Nacional de Huelga, p. 182. 
"hasta en cuanto no sea desmentida" ${ }^{73}$ Los cambios en la portada, incluso de color, mostraban que no querían ocultar su satisfacción. El cálculo es que se editaron "conservadoramente unos 100 mil” ejemplares. $^{74}$

\section{EL LADO GRIS}

Es muy difícil separar de este grupo algunos trabajos literarios o periodísticos que amplificaron el discurso oficial. Hubo muchos textos que apoyaron las tesis del gobierno o presentaron aspectos clave de la versión oficial. Eran textos que lograron una acogida porque sus autores aportaron sus habilidades y sus prestigios personales. Entre estos trabajos sobresalen por sus tiradas Tlatelolco, historia de una infamia, de Roberto Blanco Moheno, y La plaza, de Luis Spota. Según Blanco Moheno, la masacre del 2 de octubre era el resultado de una suerte de "Plan Tlatelolco" que se habían trazado los estudiantes. ${ }^{75}$ La emboscada al ejército era fruto de la "táctica de la cosecha de mártires". ${ }^{76}$ Como el movimiento estudiantil "se desinflaba cada día”, sobre todo después del informe presidencial, los jóvenes habían formado unas "columnas de seguridad" para que hicieran "los primeros disparos para desencadenar la reacción de terror en el público y de defensa de la tropa". ${ }^{77}$ Spota por su parte

73 URrutia, Trampa en Tlatelolco. Sintesis de una felonía contra MéxiCO, p. 37.

74 Martré, El movimiento popular estudiantil de 1968 en la novela mexicana, p. 170.

75 Blanco Moheno, Tlatelolco, historia de una infamia, p. 271.

76 Blanco Moheno, Tlatelolco, historia de una infamia, p. 275.

77 Blanco Moheno, Tlatelolco, historia de una infamia, pp. 279 y 280. 
imaginó al padre de una víctima de Tlatelolco, y lo transformó en un secuestrador, líder de una célula justiciera y torturadora de funcionarios gubernamentales. Sin duda era una posibilidad de esos años, pero su representación tenía, además, las fijaciones de la versión oficial. Coincidía en que la masacre sólo se explicaba con el enigma de los disparos que incitaban al ejército y pedía a sus lectores: "repasemos cuáles son los hechos comprobables" del 2 de octubre. Entre esos hechos, estaba el dato número "1. Cuando el mitin está disolviéndose, hay un balazo que abate al jefe de la tropa" ${ }^{78} \mathrm{La}$ sociedad los leyó, esta vez pagando el precio de tapa.

Afines a la argumentación oficial pero elaborados por hombres reconocidos fuera del aparato político, estos trabajos sirven para ver cómo la versión oficial necesitaba de muchas voces para sostener su discurso. Sin la puesta en juego de estos autores, el gobierno no habría tenido llegada a ciertos sectores. Si por su formato el libro de Blanco Moheno sigue al trabajo de Manuel Urrutia, el de Spota es una continuidad de jel móndrigo! Ambos fueron muy leídos y estuvieron entre los más reeditados de la época. A diferencia de aquéllos, éstos fueron editados por sellos reconocidos. Es difícil saber si estos libros le dieron una mayor credibilidad a la versión gubernamental, lo cierto es que estos trabajos eran una forma de reproducirla apuntando, como demandaba el discurso oficial, al intercambio de papeles entre víctimas y victimarios. A esa suerte de dialéctica en la que estudiantes y gobierno cambiaban, por medio de la representación, sus acciones y banderas. Los estudiantes se volvían responsables de la masacre, eran autoritarios y meticulosos planificadores

${ }^{78}$ Spota, La plaza, p. 193. 
de "la encerrona de Tlatelolco", ${ }^{79}$ y el campo oficial se volvía víctima: era emboscado, herido como el jefe de la tropa, secuestrado como el personaje de La plaza, defensor de las libertades del pueblo de México.

La plaza buscaba vincular la desesperación de las víctimas del 2 de octubre con la decisión de tomar las armas. Su personaje secuestra y tortura a un funcionario gubernamental como alternativa para expresar su malestar contra el grupo en el poder, y de este modo el relato presenta el escenario de la clandestinidad, que se combina con interrogatorios y vejaciones en una improvisada cárcel en una casa de un barrio de la ciudad. Hay mucho que analizar en este proceso de representación que unirá la masacre de Tlatelolco con la presencia en el ámbito político de unos nuevos enemigos de la sociedad. Blanco Moheno, en cambio, incorporó una faceta que ninguno de los trabajos oficiales se había atrevido a abordar: el escenario internacional. A través de su relato podemos penetrar en las opiniones oficiales sobre los actores de la izquierda latinoamericana que eran contemporáneos al PRI. Blanco Moheno dice cosas que no serían aceptables para un funcionario, pero que constituyen una visión del lugar que el priismo quería ocupar ante las ideas revolucionarias del contexto latinoamericano. A la vez, tendía un puente de interpretación entre las guerrillas latinoamericanas y la mexicana.

Para Blanco Moheno había una enfermedad en el pensamiento liberador. El ejemplo internacional de la enfermedad lo había puesto Lenin. Con esa "inteligencia llevada a sus últimos extremos" nos habría legado "una consecuencia monstruosa" a la humanidad, al querer "libertar a los

79 Blanco Moheno, Tlatelolco, historia de una infamia, p. 272. 
hombres del mañana" había provocado en los hechos que "los que existían el día de ayer" ahora estén "asesinados". Fidel Castro, Juan Domingo Perón y el Che Guevara eran sus figuras más escandalosas. El Che se presentaba como el "típico representante de estos progresistas que no son sino enfermos". La palabra enfermos se volvería bastante común en la retórica oficial de esos años: "los comunistas, los pseudocomunistas de nuestra raza indoamericana" eran "todos, enfermos sociales". ${ }^{80}$ Eran enfermos en la medida en que no se adaptaban a la gradualidad de los cambios que podían hacerse en países como México. José Revueltas era el representante local de la naturaleza psíquica del movimiento estudiantil. El ataque a Revueltas se extendía a toda su familia como un síntoma indubitable de la anormalidad de la época. De Silvestre Revueltas, el hermano músico, decía que se trataba, "desgraciadamente", de un "enfermo mental". ${ }^{81} \mathrm{Y}$ en él, un profesor respetado y querido, veía a un ser "incapaz en su trágica anormalidad", que no halló más que "organizar una nueva infamia" propia de su "espíritu desviado y morboso". Para los estudiantes en general, cabía la disculpa que también el gobierno necesitaba extender: eran pobres jóvenes sanos y normales, que "llevados de su edad, de su inmadurez, de su exceso de vida” seguían a hombres como Revueltas en "forma absolutamente inconsciente". ${ }^{82}$

La cercanía de Luis Spota con los hombres del poder es bastante conocida. Fue cercano a varios presidentes, trabajó específicamente con Luis Echeverría y Televisa, y estaba

${ }^{80}$ Blanco Moheno, Tlatelolco, historia de una infamia, pp. 90, 103 y 173.

${ }^{81}$ Blanco Moheno, Tlatelolco, historia de una infamia, p. 162.

${ }^{82}$ Blanco Moheno, Tlatelolco, historia de una infamia, p. 173. 
muy familiarizado con el problema del discurso del gobierno. Durante esos años dirigía el suplemento cultural de $E l$ Heraldo de México. En cuanto a Blanco Moheno, su apoyo al PRI era explícito, y hace poco tiempo se encontraron en los archivos de la SEGOB las cartas en las que le informaba a Luis Echeverría de los avances de su libro. ${ }^{83}$

\section{UNA GUÍA PARA EL MOVIMIENTO:}

NO HAY OTRO CAMINO QUE EL NUESTRO

El gobierno tenía presente que en la cárcel de Lecumberri - donde estaban los estudiantes y profesores detenidos del 2 de octubre - se escribían varios libros. Se había extendido tanto el temor a la cristalización de la verdad estudiantil que pocos en el gobierno parecían esconder la preocupación de haber perdido la batalla en el imaginario de la población mexicana. Las propuestas literarias que hemos reseñado hasta aquí no iban a ser suficientes para sobrevivir entre la primera docena de trabajos del campo estudiantil. La máquina narrativa oficial no estaba sino comenzando una nueva etapa. La campaña presidencial de Luis Echeverría sería una muestra de su capacidad para usar las emociones sociales en la configuración de actitudes políticas. El libro Nuevo movimiento estudiantil, de un inverosímil Antonio Caminante, era otro de los textos elaborados en el marco de esta ya frondosa historiografía oficial. Se trata de un ensayo que tenía objetivos distintos a los anteriores: quería señalarle al malestar estudiantil una ruta de acción en la llamada apertura democrática del nuevo gobierno. En apenas cincuenta páginas, bien editadas e ilustradas,

83 Rodríguez Munguía, La otra guerra secreta, p. 408. 
sin más datos editoriales que la palabra Doxa, el texto propone un giro táctico al campo estudiantil, un movimiento.

El seudónimo aludía a Antonio Machado, poeta admirado por los jóvenes politizados. Buscaba discutir los caminos de la disidencia estudiantil después de la masacre. Y llegar a la idea de que: caminante... sí hay caminos: el camino del empleo. Y para avanzar en él no habría que producir un giro ideológico, se podría seguir pensando en hacer justicia en México, no había que moverse de conceptualizaciones ni sumarse a las filas del partido. Ciertas ideas continuaban a jel móndrigo! Había que pensar en construir, no en destruir. Se dirigía al corazón de los debates existentes en torno al rumbo del movimiento. Según sus palabras, quería mostrar que "aún al precio de la sangre”, tras la masacre y la desmovilización estudiantil, el gobierno tenía muchas más “oportunidades de acción democrática” que las de la disidencia estudiantil, a las que se les habían esfumado las posibilidades de actuar políticamente. ${ }^{84}$

El gobierno quería incluir a los jóvenes en las tareas estatales, ofreciendo un camino para que los sectores opositores pudieran "ejercer el sano descontento". La enunciación de esta disposición informa por igual a estudiantes e intelectuales opositores del "ancho camino" que se les presenta, el ancho camino de la educación. Para eso, "cada estudiante debe tomar el sitio que le indiquen sus ideas y sus sentimientos, y todos juntos desplegar una acción renovadora y constructiva en el campo de la educación [...]" ${ }^{85}$ Específicamente, el movimiento posterior al 2 de octubre consistiría

84 Caminante, Nuevo movimiento estudiantil, p. 43.

85 Caminante, Nuevo movimiento estudiantil, pp. 44-45. 
en distanciarse de las equivocadas interpretaciones de "el camino de la revolución" como postura antigubernamental, para "aprovechar la apertura democrática que ahora se abre" $[\text { sic }]^{86}$

A diferencia de los anteriores, el texto fingía una amplia comprensión de la rebelión juvenil, en tanto parecía evidente que los estudiantes del país no podrían estar ajenos a "las guerras y hecatombes" del mundo, o a las "crisis del viejo capitalismo de marcado tipo estatal y dictatorial”. En todo caso, los estudiantes debían ser disculpados por estar rodeados de un ideario moderno hecho de "teorías que nada tienen de revolucionarias", un ideario que estaría buscando y celebrando el "movimiento por el movimiento mismo" ${ }^{87} \mathrm{De}$ la misma manera que se propone un cambio de eje de la incipiente cultura política juvenil, en el trabajo se exploran interpretaciones sobre las dinámicas entre teoría y práctica en esa misma juventud. Contrario a la tesis oficial de la conjura comunista, el trabajo es honesto en el análisis de la instalación del discurso marxista en México que, argumenta, se dio en el marco de una dislocación de la institucionalidad comunista. Las prácticas que debían derivarse de estos discursos no fortalecían al comunismo mexicano, sino que más bien eran prácticas anarquistas que de ningún modo aquél podía aprovechar. "El fenómeno no es exclusivo de México", se escribe, pues pareciera que muchos otros partidos comunistas de la región atraviesan "un periodo de intensa confusión y contaminación ideológica”, y están muy alejados de "las concepciones cardinales del marxismo". Era un fenómeno

\footnotetext{
86 Caminante, Nuevo movimiento estudiantil, pp. 43-44.

87 Caminante, Nuevo movimiento estudiantil, p. 11.
} 
que se asociaba al nacimiento de las guerrillas en la región. Desde "el extinto Marighela en el Brasil, los Tupamaros en Uruguay", así como las "diferentes sectas en Argentina”, y los muchos "grupos de guerrilla urbana en Guatemala, Venezuela o Colombia", todos ellos "se han dislocado de los partidos comunistas, socialistas o simplemente populistas". Sin embargo, y más allá de las múltiples posiciones existentes en todos estos procesos y actores, no era menor el hecho, o por lo menos llamaba la atención, de que en conjunto, tantos sectores sociales "han querido ampararse todavía bajo el rubro del marxismo". 88

La mirada gubernamental se revela en el interés de ciertos fenómenos sociales y en su intención de construir una perspectiva desde la que interpretarlos. El trabajo es crítico y a la vez busca visibilizar los debates acerca del foco guerrillero, los que ve como intentos de "hacer creer a los mexicanos" de que ya "no hay otra solución" que la de las armas. Que en definitiva "la solución violenta" para "acelerar la marcha de la historia” es el camino de esta generación. Esta "santificación de la violencia”, en el caso mexicano, no conduciría sino a que "salten al primer plano de la vida pública inclinaciones dictatoriales latentes en algunas esferas" ${ }^{89}$ Sin enunciarlo, se dejaban abiertas las premisas para el apotegma de que era necesario optar entre Echeverría o el fascismo. Quizá una de las cuestiones más interesantes es que, a diferencia de la desesperación que transmiten Manuel Urrutia o Sánchez Vargas, que casi se sienten vencidos en el terreno de la opinión pública, éste ya tiene el tono triunfal del grupo echeverrista.

88 Caminante, Nuevo movimiento estudiantil, pp. 17-18.

${ }^{89}$ Caminante, Nuevo movimiento estudiantil, p. 29. 
Su optimismo es acerca del horizonte del régimen, no sólo frente a los estudiantes, sino ante los otros partidos políticos. Produce también una argumentación en torno a las posibilidades del PRI de establecer nuevos vínculos con la juventud como una forma de romper con el malestar. El asunto era que la juventud no sólo estaba descontenta con el gobierno, estaba descontenta en muchos sentidos y con gran parte de los actores políticos. A ninguna de las fuerzas políticas existentes le sería fácil capitalizar ese malestar. "El PRI, para los estudiantes, es demasiado oficial, excesivamente institucional" y tiene que ver "con lo establecido". La suerte del principal antagonista era idéntica: "el PAN les huele mucho a conserva reaccionaria”. La retórica panista debía parecerles "mal disfrazada", en su "desabrida palabrería entre cristianizante y liberal”. Tampoco en la izquierda tenían ofertas para la juventud, y resultaba evidente que "el apacible y anémico socialismo del pps les dice muy poco [...]". ${ }^{90}$ Para tranquilidad del régimen político, el comunismo local que tanto había preocupado al gobierno, en realidad había enfrascado a la juventud en "pequeños núcleos" que seguramente no podrían desafiar el control de la presidencia. "Ya en Francia recibieron el nombre clásico de grupúsculos”, una multiplicación de tendencias "trotskistas, maoístas, castristas, guevarista $[\ldots]$ nihilistas y anarquistas naturales, anarquistas por temperamento, aunque no hayan leído un solo folleto de esa tendencia". ${ }^{91}$ Este era el marco explicativo de la propuesta de moverse de las posiciones rebeldes y proyectos políticos

90 Caminante, Nuevo movimiento estudiantil, pp. 7-8.
91 Caminante, Nuevo movimiento estudiantil, pp. 7-8. 
sin futuro, hacia un lugar en la burocracia estatal. Específicamente, en la academia, en las escuelas y en las aulas.

\section{LA CONJURA INTERIOR DEL EJÉRCITO}

El general Luis Gutiérrez Oropeza, jefe del Estado Mayor Presidencial, que se encargaba de la protección de Díaz Ordaz en 1968, también había asumido el encargo de escribir. Iba a atacar a Lázaro Cárdenas, porque el gobierno sentía el desafío de sus vínculos con los estudiantes. Los avances de Gutiérrez Oropeza se toparon con la muerte de Cárdenas en 1970, de modo que tuvieron que pasar muchos años para que ya sin apoyo en el ejército sacara de sus archivos este intento y lo concluyera como La realidad de los acontecimientos de 1968. En su tesis, Cárdenas no había logrado aceptar el fin de su orbitancia política. Se había sacudido a Calles, pero para construir su propia "hegemonía política, no sólo para el país sino para la persona de los futuros presidentes". Quiso ser para siempre "la voz cantante" de los gobiernos del partido. ${ }^{92}$

Según Gutiérrez Oropeza, el cardenismo era responsable porque el conflicto sólo se entendía a partir de las políticas que había implementado desde su presidencia de 1934 a 1940. Específicamente, cuando "fundó las escuelas Normales Rurales, verdaderos centros de adiestramiento marxista”, y "el Instituto Politécnico Nacional, núcleo ideológico comunista". ${ }^{93}$ En cuanto a la organización estudiantil de 1968, Gutiérrez Oropeza decía que "Cárdenas los animó y

92 Gutiérrez Oropeza, La realidad de los acontecimientos de 1968, p. 5.

93 Gutiérrez Oropeza, La realidad de los acontecimientos de 1968, p. 5. 
ayudó ofreciéndoles también protección en los contratiempos que tuvieron". ${ }^{94}$ Esta posición contra Cárdenas separaba definitivamente a Gutiérrez Oropeza del general García Barragán, miembro de ese sector.

En lo que hace a 1968, asumió el argumento de la conspiración comunista, en clara sintonía con las opiniones de Díaz Ordaz. La tesis de la conspiración, presentada como ningún otro texto de la versión oficial, es un esfuerzo por hilvanar los episodios que, a la manera de una investigación histórica, permitirían sostener el argumento de que el comunismo internacional tuvo un plan de desestabilización que llegó a México. Los obreros y campesinos le habían cedido el paso al sector estudiantil como actores históricos. Para mostrarlo, ensaya una acumulación de manifestaciones de descontento estudiantil en el mundo, con los que se propone interpretar este giro pragmático del comunismo, de cambiar su sujeto histórico tradicional. Se trata de una cronología que va del 8 de enero al 25 de diciembre de 1968, en la que aparecen noticias de los cinco continentes. Como si bastara con mencionar todo lo que había ocurrido ese año que tuviera que ver con los estudiantes y la política, para que el argumento actuara orgánica y convincentemente.

Así, asocia que todo tiene que ver con el movimiento estudiantil mexicano: los Zengakuren de Japón que se oponen a la presencia e inversiones estadounidenses, los estudiantes de la Universidad de Argel que quieren democracia sindical, la huelga de la Universidad de Columbia en defensa de Harlem, los 3000 estudiantes en Chile que toman la rectoría de Santiago,

94 Gutiérrez Oropeza, La realidad de los acontecimientos de 1968, p. 21. 
los bogotanos que rechazan la entrada de la policía a la Universidad, los 50000 huelguistas universitarios en Turquía, los que piden la libertad del joven presidente de la Federación Universitaria de Perú, los que protestan contra el nombramiento de un maestro negro en la Universidad del Cabo en África, la manifestación en Chicago, el enojo en Jamaica contra la prohibición que pesa sobre un profesor, los preparatorianos de Naplouse que demandan la liberación de Palestina, el convulsivo cierre del liceo Tokolin de Togo, la lapidación de un ministro por colegiales en la India, la huelga del liceo de Ingeniería Civil de Tananarive en Madagascar. Para Gutiérrez Oropeza, todo "lo anterior pone de manifiesto" el "plan trazado por la Unión Soviética” para alterar la vida interna de cada nación con el fin de expandir el comunismo como forma de gobierno. Los disturbios han llegado a México en el momento justo. Y “tanta exactitud”, tanta "sincronización admirable”, de algún modo "matemática” de un episodio con otro, lo explica. ${ }^{95}$ La preocupación que parece alentar la edición tardía es la posibilidad de que el PRI perdiera la presidencia en 2000 a manos de Cuauhtémoc Cárdenas. Y con ello, que la impunidad de la que había gozado junto con todos los miembros de la élite represiva se terminara. Ve al PRI en un ocaso inevitable: "un partido obsoleto, dividido, carente de figuras de importancia, en donde ha surgido un feroz canibalismo" que dejará al ejército a merced de la revancha de las víctimas. ${ }^{96}$ En este contexto, lo más temible parecía ser el Partido de la Revolución Democrática (PRD), que no era sino "las nue-

95 Gutiérrez Oropeza, La realidad de los acontecimientos de 1968, pp. 24-29.

${ }_{96}$ Gutiérrez Oropeza, La realidad de los acontecimientos de 1968, p. 77. 
vas siglas del comunismo" y en el que parecían imponerse el "pensamiento del general Cárdenas a través de su hijo, que al igual que su padre, se siente iluminado". ${ }^{97}$ Frente a esta posibilidad, Gutiérrez Oropeza quiere que el ejército no se vuelva a someter a los civiles: "la patria es permanente y la política transitoria”, dice. A diferencia de la política, "el ejército nació con la Patria”, los civiles son un efecto de la organización militar posrevolucionaria. ${ }^{98}$

Citando la doctrina política de Primo de Rivera, enfatiza sobre la amenaza que se cierne sobre el ejército ante la crisis:

Cuando es lo permanente mismo lo que peligra; cuando está en riesgo la misma permanencia de la Patria, el ejército no tiene más remedio que deliberar y elegir. Si se abstiene, por una interpretación puramente externa de su deber, se expone a encontrarse, de la noche a la mañana, sin nada a qué servir. En presencia de los hundimientos decisivos, el ejército no puede servir a lo permanente más que de una manera: recobrándolo con sus propias armas. Y así ha ocurrido desde que el mundo es mundo, siempre ha sido a última hora un pelotón de soldados el que ha salvado la civilización. ${ }^{99}$

Esta preocupación por incidir en las decisiones militares del momento es, sin duda, una de las causas por las que este trabajo no logró transgredir los espacios bibliotecarios del ejército incluso ahora. Es posible que esto ayude a entender por qué este general sería responsabilizado de la masacre

97 Gutiérrez Oropeza, La realidad de los acontecimientos de 1968, p. 78.

98 Gutiérrez Oropeza, La realidad de los acontecimientos de 1968, p. 81.

99 Gutiérrez Oropeza, La realidad de los acontecimientos de 1968, p. 81. 
de Tlatelolco por el periodista Julio Scherer en 1998. ${ }^{100}$ De algún modo, este problema de su libro y la tardía - y por muchas razones dudosa - acusación dentro de las fuerzas armadas ilustra sobre un modo de zanjar las contradicciones dentro de esta polisémica y polifónica voz oficial. Las contradicciones y diferencias fueron también factores de silenciamiento dentro de una élite que en momentos como éste evidencia su recambio, lo cual debe llamar la atención sobre la opacidad misma de las opiniones, intereses y posiciones del grupo en el poder en éste y otros momentos de la vida política.

De la década del setenta había que aprender lo siguiente: los militares "han servido fielmente a la República en momentos de crisis", y no sólo no han sido cuidados por los actores civiles, sino que se han visto postergados por la incorporación de "subversivos" en el gobierno. De qué otro modo podía entenderse que "los instigadores de dichos movimientos gocen de apoyo, y formando parte ya del gobierno", incluso llegando al punto de que "impongan su autoridad sobre el ejército, aun en perjuicio de la patria". ${ }^{101}$ El ejército nunca perdería su importancia para el equilibrio político, pero el costo de actuar en defensa de los civiles en el gobierno podría estar cerca de pagarse: "los problemas que ha habido en México los han creado los ex-integrantes o integrantes del sistema", y "cuando los políticos no han podido solucionarlos, entran los militares para resolvérselos”. Piensa que el ejército no debe participar en los conflictos sociales porque éstos necesitan "soluciones políticas, no

100 Scherer y Monsiváis, Parte de guerra. Tlatelolco 1968.

101 Gutiérrez Oropeza, La realidad de los acontecimientos de 1968, p. 81. 
de fuerza", y porque tras los enfrentamientos "los políticos cosechan los aplausos, [y] los militares los señalamientos". ${ }^{102}$ En otras palabras, "si los resultados son favorables, los políticos se ufanan de que se debe a su acertado desempeño", en cambio, "si por el contrario los resultados son malos, todas las responsabilidades se le fincan al Ejército". ${ }^{103}$

No es inocente Gutiérrez Oropeza al querer ser vocero del malestar orgánico del ejército con el papel que los tecnócratas ocuparon luego de la llamada guerra sucia. Los soldados se sentían fundamentales en el exterminio de la disidencia. Argumenta que en la larga crisis de esta "simbiosis" entre las fuerzas armadas y el "sistema-gobierno", cuando los generales no estaban de acuerdo con el gobierno "lo amenazaban con un levantamiento o golpe militar", como fue el caso de los generales "Serrano, Gómez Estrada, Cedillo y Almazán”. No obstante, o como resultado de estas desavenencias, a partir del "gobierno del Lic. Miguel Alemán" la presencia de las fuerzas armadas "fue reemplazada por los profesionistas". Desde 1946, dice Gutiérrez Oropeza, "todos los puestos que antes ocupaban los militares recaían ahora en los grupos de poder que empezaron a manipular a las dos principales casas de estudios: la Universidad Nacional Autónoma de México (UNAM) y el Instituto Politécnico Nacional (IPN), influyendo en la política de México". E igual que el ejército cuando estaba inconforme, "cuando los integrantes de estos dos planteles no están de acuerdo con el gobierno, se valen de los estudiantes - convertidos en simples herramientas - para amenazar con

102 Gutiérrez Oropeza, La realidad de los acontecimientos de 1968, pp. 81-82.

103 Gutiérrez Oropeza, La realidad de los acontecimientos de 1968, p. 89. 
manifestaciones, mítines y otros desórdenes”. ${ }^{104}$ En la confusión, el estudiantado era también fuerza de los civiles en el gobierno.

De este modo, la explicación de la coyuntura de 1968 en sus palabras tiene que ver con decisiones de la élite profesionista contra la militar. Los civiles cerraban filas contra el ascenso de cualquier miembro de las fuerzas armadas. Fueron Emilio Martínez Manautou y Luis Echeverría Álvarez, funcionarios y aspirantes a la presidencia, los que "iniciaron y alimentaron este sentimiento, o sea, que un militar no debería llegar a la Presidencia del país, sentimiento que hasta nuestros días subsiste”. Más allá de que habría que indagar en quienes sostenían explicaciones similares, Gutiérrez Oropeza esgrime que se trata de una oposición de los civiles a la ética extraordinaria de la organización militar: "los civiles saben que los militares se guían por cartabones de organización, responsabilidad y patriotismo". Y por eso "les temen". ${ }^{105}$

En su argumento, el secretario de la Presidencia le "echaba la leña al problema, para que se quemaran el Jefe del Departamento del Distrito Federal y el Secretario de Gobernación”, y esperaba poder oficiar "el papel del gran conciliador entre los integrantes del CNH y el gobierno”. ${ }^{106}$ La prueba de los vínculos que Martínez Manautou había tejido con un "grupo de intelectuales" universitarios se habría dado en septiembre de 1969, a poco de las elecciones. Este grupo había firmado un "panfleto intitulado: Democracia o Autoritaris$m o$, en donde insinuaban que el Presidente era un autócrata

104 Gutiérrez Oropeza, La realidad de los acontecimientos de 1968, p. 83.

105 Gutiérrez Oropeza, La realidad de los acontecimientos de 1968, p. 83.

106 Gutiérrez Oropeza, La realidad de los acontecimientos de 1968, p. 85. 
y hacían consideraciones sobre el destino inmediato del país en la sucesión presidencial” " ${ }^{107}$ Por otro lado, creía que el secretario de Gobernación, "con más maña, malicia, habilidad y un comportamiento antipatriótico, negoció, manipuló en su provecho el desarrollo de los hechos del '68". ${ }^{108}$ En su caso, la prueba del uso del movimiento estudiantil se encontraba en "la inclusión de muchos de estos sujetos del movimiento del "68 en el gobierno". Había sido "un pago, una apertura negociada”. Así, con "maestros y líderes”, “especialmente con los de la UNAM", conformó su gabinete y "los designó funcionarios, embajadores y hasta Secretarios de Estado, pagando así la deuda a la alianza contraída con este grupo". ${ }^{109} \mathrm{La}$ incorporación en el gobierno de "personas con tendencia comunistoide" había contrariado profundamente a las fuerzas armadas, y le parece fundamental que se exprese lo que las fuerzas armadas "han sentido cuando se enteraron de nombramientos semejantes [...]". ${ }^{110}$

Hacia el final, el autor nos revela las razones por las que regresa a este momento en que "los integrantes de este grupo-sistema" produjeron una larga y "verdadera lucha por alcanzar el poder". Se trata de una "lucha que se inicia al integrarse el gabinete del Presidente entrante, si no es que antes". ${ }^{111}$ Esta lucha, evidentemente, no explica otras tensiones latentes en el país, que se admiten como el problema

107 Gutiérrez Oropeza, La realidad de los acontecimientos de 1968, p. 85. 108 Gutiérrez Oropeza, La realidad de los acontecimientos de 1968, pp. 85-86.

109 Gutiérrez Oropeza, La realidad de los acontecimientos de 1968, p. 86.

110 Gutiérrez Oropeza, La realidad de los acontecimientos de 1968, pp. 86-87.

111 Gutiérrez Oropeza, La realidad de los acontecimientos de 1968, p. 87. 
"para asimilar y controlar a nuevos sectores sociales que surgen políticamente o se van fortaleciendo en el seno de la sociedad", como podrían haber estado expresando los conflictos estudiantiles. Pero "el estado mexicano no estaba ni está preparado, ni capacitado para hacerle frente" a estos nuevos sectores "a través de sus aparatos ideológicos", de modo que es evidente que la "familia política situada al frente del actual sistema se ha sentido verdaderamente incapaz" de enfrentar este empoderamiento civil. Y tarde o temprano perderán el poder.

CONCLUSIONES

Hasta aquí hemos mostrado la importancia de historizar el discurso oficial. Nos permitió acceder a algunas concepciones de la élite mexicana ante una crisis política especial. Se trata de ideas que afectan a las representaciones de una época, tal como sucede con la versión oficial y la historiografía de 1968. Las visiones contenidas en estos trabajos permiten comprender mejor las decisiones gubernamentales y situar la procedencia de algunos argumentos. El caso ha mostrado además que una voz intencionada, donde se mezclan la impostación y el camuflaje, se resiste a la interpretación. Una prosa que se hace con trampas y ecos para confundir al lector es una prosa autoritaria que concibe al lector como enemigo. A su vez, la versión oficial se manifestó a partir de un acontecimiento emblemático, pero lo trasciende como problema y como práctica. Las versiones oficiales no nacieron con esta masacre, ni terminaron con ella. Es decir, hay un problema más importante que la versión oficial de 1968, y es el de una élite que con el tiempo ha ido renovando sus técnicas 
narrativas. Esto hace que los significados y temas de ésta compartan su importancia con los saberes y las artes que se pusieron en juego después de la masacre. Estas artes y saberes tienen historicidad, evolucionan, se estancan o naturalizan, forman parte de una cultura política específica y definen modelos de comunicación.

El recorrido que hemos hecho, por otra parte, demanda mejores abordajes de varios asuntos. Uno de ellos tiene que ver con las circunstancias de cada uno de estos textos: hay mucho que conocer sobre escritores y temáticas que aquí apenas fueron señaladas. Entre ellas, las ideas que las fundamentan e hicieron posible a la versión oficial como estrategia política. La voz oficial ha sido la gran articuladora de las dinámicas nacionales, produciéndole centros y periferias al debate social, de modo que interpretar estas prácticas es conflictivo y necesario. Además, es preciso penetrar historiográficamente en el campo oficial, y teorizar sobre una retórica, que como hemos visto, escapa a las clasificaciones existentes. La demanda de mejores narradores, la existencia de escritores ocultos, de lectores enemigos y editoriales fantasma, exige repensar los horizontes de enunciación de los actores implicados y el aparato conceptual con que caracterizamos a la opinión pública en tiempos autoritarios.

El estudio del pasado reciente mexicano, por otro lado, está cargado de silencios. Si esta narrativa tiene pantanos, hay que considerar que es sobre todo un territorio de lagunas. La desclasificación y reclasificación de documentación política de los años setenta ${ }^{112}$ y la batalla de la prensa por

${ }^{112}$ Los archivos represivos fueron desclasificados en 2001 y puestos en el Archivo General de la Nación durante los primeros meses del gobierno de Vicente Fox. En 2012, se sancionó una ley bajo cuyo amparo se consi- 
acceder a información del gobierno hablan del valor que los poderes actuales le otorgan a los documentos oficiales del pasado y de la opacidad ejercida en su manejo. Esto le agrega urgencia a una tarea compleja y sobre la que confluyen intereses disciplinarios y grupos sociales que desean que el pasado incorpore sus experiencias y expectativas. Está claro que el movimiento estudiantil debió sufrir, además de los disparos de metal, una serie de disparos de papel. Y que muchos otros opositores de los años siguientes correrían la misma suerte. Gran parte de la narrativa de los opositores ha sido una respuesta a estas operaciones. Por ello, el estudio de la narrativa oficial ayuda tanto a contextualizar los escenarios de movimientos sociales, como a comprender dinámicas de enunciación que hoy envuelven a los actores políticos y a la sociedad.

\section{SIGLAS Y REFERENCIAS}

AGN, IPS Archivo General de la Nación, Fondo de Investigaciones Políticas y Sociales, México.

AGN, DFS Archivo General de la Nación, Dirección Federal de Seguridad, México.

AGN, SEDENA Archivo General de la Nación, Secretaría de la Defensa de la Nación, México.

ANónimo

jel móndrigo! Bitácora del Consejo Nacional de Huelga, varias ediciones, México, Alba Roja, s/f.

deran hoy como Archivos históricos confidenciales, y actualmente están restringidos a los historiadores. 
Agee, Philip

Inside the Company: CIA Diary, Londres, Penguin Books, 1975.

Aguirre, Efrén

El Excélsior de Scherer, México, s/editorial, 1973.

Blanco Moheno, Roberto

Tlatelolco, historia de una infamia, México, Diana, 1969.

Caminante, Antonio

Nuevo movimiento estudiantil, México, Doxa, s/f.

Courier, Paul-Louis

Pamphlet des pamphlets, París, 1824.

DARnTON, Robert

El diablo en el agua bendita o el arte de la calumnia de Luis XIV a Napoleón, México, Fondo de Cultura Económica, 2014.

Doyle, Kate

"Los muertos de Tlatelolco", The National Security Archives, $1^{\circ}$ de octubre de 2006, http://www2.gwu.edu/ nsarchiv/ NSAEBB/NSAEBB201/index2.htm

FARGE, Arlette

Subversive Words. Public Opinion in Eighteenth-Century France, University Park, Penn, The Pennsylvania State University Press, 1995.

Godines, Prudencio Jr.

¡Qué poca mad...era la de José Santos Valdés!, s/d, $3^{a}$ ed., 1969.

GonZÁlez de Alba, Luis

Los días y los años, México, Ediciones Era, 1971. 
Gutiérrez Oropeza, Luis

La realidad de los acontecimientos de 1968 [México], edición del autor, 1996.

GuZmán, León

“En el Campo Militar Número Uno: la gran farsa”, en revista por qué?, 20 (1968), pp. 20-26.

"Graves y sensacionales denuncias de Sócrates A. Campos Lemus”, revista por qué?, 21 (1968), pp. 4-7.

“¿Y las denuncias de Sócrates?”, en revista por qué?, número extra, pp. 22-25.

Huamán, Carlos y Francisco Xavier Solé (coords.)

Imaginaturas en el tiempo. Los héroes en la ficción de la historia, México, Centro de Investigaciones sobre América Latina y el Caribe, Universidad Nacional Autónoma de México, Universidad Autónoma del Estado de México, 2010.

IBARRA, Leoncio

Danny, el sobrino del Tío Sam. Biopsia de un cínico, México, edición privada, 1974.

Krauze, Enrique

La presidencia imperial. Ascenso y caída del sistema político mexicano (1940-1996), México, Tusquets, 2013.

Martré, Gonzalo

El movimiento popular estudiantil de 1968 en la novela mexicana, México, Universidad Nacional Autónoma de México, 1986.

Moya Palencia, Mario

El México de Egerton: 1831-1842, México, Porrúa, 1991. 
Ortega, Gregorio

Fernando Gutiérrez Barrios. Diálogos con el hombre, el poder y la política, México, Planeta, 1995.

Paz, Octavio

El laberinto de la Soledad / Postdata / Vuelta al laberinto de la soledad, México, Fondo de Cultura Económica, 2000.

RAMírez, Ramón

El movimiento estudiantil de México (julio/diciembre de 1968), México, Era, 1998, 2 volúmenes.

Rodríguez Munguía, Jacinto

La otra guerra secreta Los archivos probibidos de la prensa $y$ el poder, México, Grijalbo, 2007.

SAWYER, Jeffrey K

Printed Poison. Pamphlet propaganda, faction politics and the public sphere in early seventeenth-century France, Berkeley, University of California Press, 1990.

Scherer, Julio y Carlos Monsiváis

Parte de guerra, Tlatelolco 1968. Documentos del general Marcelino Barragán. Los hechos y la historia, México, Nuevo Siglo Aguilar, 1999.

Spota, Luis

La plaza, México, Joaquín Mortiz, 1972.

TAsso, Pablo

“La historiografía oficial de 1968", tesis de doctorado en historiografía, México, Universidad Nacional Autónoma de México, 2014.

“El Móndrigo y la literatura del poder”, en Huamán y Solé (coords.), 2010, pp. 131-141. 
Urrutia Castro, Manuel

Trampa en Tlatelolco. Sintesis de una felonia contra México, México [Manuel Urrutia Castro], 1969.

Vargas Vila, José María

Alba Roja, París, Barcelona, Ramón Sopena, 1918. 